\begin{tabular}{|l|l|l||}
\hline \multicolumn{2}{|c|}{ PublisherInfo } \\
\hline \hline PublisherName & $:$ & BioMed Central \\
\hline \hline PublisherLocation & $:$ & London \\
\hline \hline PublisherImprintName & $:$ & BioMed Central \\
\hline \hline
\end{tabular}

\title{
Mother nurture
}

\begin{tabular}{|l|l|l||}
\hline \multicolumn{2}{|c|}{ ArticleInfo } \\
\hline \hline ArticleID & $:$ & 3964 \\
\hline \hline ArticleDOI & $:$ & $10.1186 /$ gb-spotlight-20010125-01 \\
\hline \hline ArticleCitationID & $:$ & spotlight-20010125-01 \\
\hline \hline ArticleSequenceNumber & $:$ & 35 \\
\hline \hline ArticleCategory & $:$ & Research news \\
\hline ArticleFirstPage & $:$ & 1 \\
\hline \hline ArticleLastPage & $:$ & 2 \\
\hline \hline & & RegistrationDate : 2001-01-25 \\
ArticleHistory & $:$ & OnlineDate $\quad$ 2001-01-25 \\
\hline \hline ArticleCopyright & $:$ & BioMed Central Ltd2001 \\
\hline \hline ArticleGrants & $:$ & \\
\hline \hline ArticleContext & $:$ & 130592211 \\
\hline \hline
\end{tabular}




\section{Jonathan B Weitzman}

Email: jonathanweitzman@hotmail.com

Genomic imprinting is characterized by epigenetic regulation of mRNA expression from a single parental allele. The two parental alleles of imprinted genes are differentially methylated. The mouse gene Peg3 is imprinted and has been shown to control the maternal nurturing of newborn pups in mice. In the January Genomics, Murphy et al. show that the human homolog of Peg3 is also imprinted (Genomics 2001, 71:110-117). They identified a CpG island (CpG islands are much more frequent around imprinted genes than elsewhere in the genome) in the promoter of the human Peg3 gene that exhibits differential methylation in adult tissues. SNP analysis of fetal tissue samples revealed that the Peg3 gene is mono-allelically expressed. Paternal allele expression persists post-natally in adult brains and ovaries. This is the first report of imprinted loci on chromosome 19. Perhaps those who feel they were neglected as children should check their mother's Peg3 status.

\section{References}

1. Genomic imprinting in mammalian development: a parental tug-of-war.

2. Peg3 imprinted gene on proximal chromosome 7 encodes for a zinc finger protein.

3. Regulation of maternal behavior and offspring growth by paternally expressed Peg3.

4. Genomics, [http://www.geneimprint.com] 